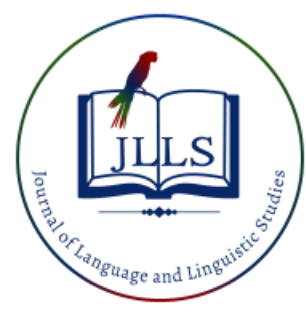

Available online at www.jlls.org

JOURNAL OF LANGUAGE

AND LINGUISTIC STUDIES

ISSN: $1305-578 \mathrm{X}$

Journal of Language and Linguistic Studies, 16(3), 1611-1620; 2020

\title{
The metadiscursive aspects of advice giving: hedging and boosting in an agony aunt's column
}

APA Citation:

\author{
Suhan Akıncı Oktay a 1 iD \\ ${ }^{a}$ Hacettepe University, Ankara, Turkey
}

Akıncı Oktay, S. (2020). The metadiscursive aspects of advice giving: hedging and boosting in an agony aunt's column. Journal of Language and Linguistic Studies, 16(3), 1611-1620.

Submission Date:23/07/2020

Acceptance Date:07/08/2020

\begin{abstract}
It is a well-known fact that advice-giving practices may differ from culture to culture. While some societies such as British culture refrain from giving advice, others such as Turkish may prefer to give advice perceiving it as an indication of solidarity. Thus, precautions for preventing this nature of advice is taken by language itself in a systematic way through the employment of metadiscoursive elements. Thus, taking advice as a starting point for understanding metadiscursive aspects of language, this study will observe the tendencies in advice-giving in digital discourse through hedges and boosters. The data were analysed quantitatively and qualitatively, and patterns in the employment of hedges and boosters were uncovered. In addition, contexts in which the use of metapragmatic items were identified and contrasted to find out the functions of hedge and booster preferences in advice-giving. The findings of the study indicate the use of hedges and boosters in speech acts and their interpretation should be evaluated in terms of the use of that specific speech act and the tendencies cultures use in advice-giving is uncovered through this study.
\end{abstract}

(C) 2020 JLLS and the Authors - Published by JLLS.

Keywords: Hedges; boosters; metadiscourse; online advice-giving

\section{Introduction}

Advice is an important aspect of human nature. When there is a problem people try to solve that problem through advice giving. Advice giving is culture-specific. For example, advice-giving is facethreatening in British culture or is welcomed in another culture. Therefore, precautions for preventing this nature of advice is taken by language itself in a systematic way by the employment of hedges and boosters. Hedging has the effect of decreasing epistemic commitment and expanding discursive space and it is realized by some linguistic resources such as appearance-based evidential verbs (it seems, it appears that), mental process verbs (the research suggests, indicates), modal verbs of probability (may, might, could), approximate adverbs (generally, likely, possibly), downtoners and minimizers (somewhat, almost, nearly) (Lancaster \& Aull 2014, p.10). Contrary to hedging, boosters increase the epistemic commitment and they are realized through amplifying and intensifying adverbs such as

\footnotetext{
${ }^{1}$ E-mail address: suhanoktay@ hacettepe.edu.tr
} 
absolutely, clearly, definitely, surely. In other words, users of languages employ hedges and boosters either to lessen or strengthen their force of utterance and they are able to create a different effect via these linguistic units.

According to Kussmaul (1997, p.74) a hedge is 'hiding behind a hedge'. What this definition indicates is that the author of the text refrains from taking responsibility for the propositional truth of his utterance and downtoning what he is proposing and aims to appear more objective to the audience. Kussmaul (1997) mentions the fact that the interpretation of hedges should be understood according to the type of speech act used.

When the dictionary definition of hedges are taken into consideration, most important entry for linguists on hedges is 'a cautious or evasive statement; and verb (intransitive) to evade decision or action, especially by making non-committal statements (Collins English Dictionary). Starting with this definition, Scholars have different points of view about hedging and they indicate its functions according to their opinion regarding them. The definition of hedging is known to have started with Lakoff and according to Lakoff (1972, p.471) hedges are defined as 'words or phrases whose job is to make things fuzzy'. According to his point of view, the sentences may be true to a certain extent or if they are false they can be false to a certain extent, but all in all they are neither true nor false completely in essence.

However, from a different perspective hedges and boosters can act as regulators of politeness and face notions and this point of view was put forward by Brown and Levinson (1987). In their theory, hedging gains face-preserving status and regulates social relations. Brown and Levinson (1987) state that hedges modify illocutionary force' either by mitigating or softening a piece of discourse and achieve politeness as a result of this mitigation or softening.

From politeness perspective, hedges prevent direct communication and they are realized in a cautious manner and this 'cautiousness' can be interpreted in terms of the notion face (Spencer-Oatey \& Ruhi, 2007) which can be explained by the fact that people pay attention and use hedges not to threaten the face of the other party a person is interacting with.

According to Spencer-Oatey (2008, p. 23) while boosters increase the force of the speech acts, hedges reduce or weaken this force. Although hedging and boosting is described as a technique valid only for academic writing, the use of hedges and boosters in informal settings and everyday life is an indication that it can be observed in other settings as well and advice-giving is one of those settings where scholars can observe them and it is necessary to study the relation between advice-giving and the employment of metadiscursive elements like hedges and boosters.

\subsection{Literature review}

Advice giving is a common activity that people encounter in their daily life. A part from the presence of advice in personal level among friends, it can be observed in institutional settings as well (Locher, 2006). According to Locher (2006) advice-giving is a context-sensitive concept and what this may mean is that it needs to be studied in its own right as it is not possible for the advice given in a certain context to be similar with an advice in another setting.

Advice has been studied extensively by Locher (2006) in agony aunt's column and she classified hedges and boosters as strategies in terms of politeness strategies. Advice columns have been investigated by some scholars. Locher (2006) studied American advice column extensively from many perspectives such as discourse, identity and politeness. Morrow (2012) also dealt with advice giving in Japanese online advice column from politeness perspective. In Turkish context Bayraktaroğlu (2001) studied face to face interaction and as a result of the study she found that Turkish advice-giving is sensitive to relations and changes according to whether the relations between adviser and advisee are intimate or not. What she means is that when the adviser and advisee had intimate relations between 
each other, advice was expected and it was a way to build rapport inside friendships. Thus, there can be more studies concerning advice in Turkish context in order to uncover how advice acts within Turkish context.

\subsection{Research questions}

The research question of the study is as the following:

- What are the common forms of hedges and boosters in advice texts?

\section{Method}

The data was gathered from the traditional Turkish advice columnist's site 'Güzin abla' which appears digitally in a local newspaper. The first person to give advice to advice-seekers was Güzin Sayar and upon her death in 2006, her daughter (Feyza Algan) continued her mission and started giving advice in the same newspaper column. She gives advice to advice-seekers on every problem they face ranging from love matters, beauty, marriage to health problems and many other problems that people experience in life. Since before 2007 the first agony aunt was giving advice to the advice seekers, the data was collected from the second generation agony aunt's period starting from 2007 to 2020 .

\subsection{Data Analysis}

According to table 1, the data analysis of the study was conducted by an eclectic taxonomy carried out by Bayyurt (2010), Doyuran (2009) and Yarar (2001):

Table 1. Categorization of Hedging devices and Boosters

\begin{tabular}{|c|c|}
\hline Categories & Examples \\
\hline \multicolumn{2}{|l|}{ A: HEDGES } \\
\hline Epistemic Hedges & $\begin{array}{l}\text { adverbials (e.g., k1smen 'relatively', kolayca 'easily', tabi ki 'of course', } \\
\text { tamamen 'entirely'), epistemic modals (e.g., ability markers -AbIl+- } \\
\text { Ir);meli permutations(meli+dIr); acak permutations (acak+dIr), epistemic } \\
\text { verbs (e.g., belirtmek 'indicate', önermek 'suggest') }\end{array}$ \\
\hline Lexical Hedges & az 'few', belki 'maybe', bir tür 'kind of' \\
\hline Possibility hedges & belki 'perhaps/possibly', muhtemelen 'perhaps' \\
\hline Downtoners & $\begin{array}{l}\text { kısmen 'partly', neredeyse 'nearly', oldukça 'fairly/somewhat', yaklaşık } \\
\text { 'more or less' }\end{array}$ \\
\hline Assertive Pronouns & $\begin{array}{l}\text { biri/birisi ‘somebody/anybody', bir kimse 'someone', bir şey 'something' } \\
\text { (i.e., any- and some- words) }\end{array}$ \\
\hline Adverbs of Frequency & $\begin{array}{l}\text { bazen/nadiren 'occasinally', sıklıkla 'often', çoğunlukla 'frequently', } \\
\text { genellikle 'usually' }\end{array}$ \\
\hline $\begin{array}{l}\text { Self-mention (Direct/Indirect } \\
\text { Person markers) }\end{array}$ & ben 'I', biz 'we', benim 'my', insanlar 'people' insanların 'people's' \\
\hline \multicolumn{2}{|l|}{ B: BOOSTERS } \\
\hline Universal Pronouns & Her- 'Every', Hiç- 'No-' \\
\hline Amplifiers & Çok 'extremely', aşırı 'extremely', tamamen 'completely' \\
\hline Emphatics & $\begin{array}{l}\text { Asla 'no way', elbette 'sure', muhakkak 'sure' } \\
\text { It is important 'önemlidir.' , It is essential 'gereklidir.' }\end{array}$ \\
\hline
\end{tabular}




\subsection{Data collection}

The data for this study was collected in two stages. In the first stage, the data were transcribed and the frequencies of the hedging devices in the data were identified and the contexts in which various categories of hedging devices were employed.

\section{Results and Discussion}

The following table displays the use of hedges and boosters in the agony aunt's advice data:

Table 2. Total number of Hedges and boosters in the agony aunt's advice data:

\begin{tabular}{lll}
\hline & Number & Frequency \\
\hline Total hedges & 280 & $63.3 \%$ \\
Total boosters & 162 & $36.6 \%$ \\
Total & 442 & 100 \\
\hline
\end{tabular}

According to table 3, hedges were more frequently used than boosters in advice letters written by the agony aunt. Hedges formed 63,3\% (280), while boosters 36,6\% (162) of the corpus.

Since advice-giving and hedging are both culturally determined, it can be observed that advice-giving is cautiously carried out by the use of hedges in order not to impose a proposition on the problem-seekers while advising and save his face as a result (Locher, 2006, p.114) (Brown \&Levinson, 1987). Hyland \&Hyland 2012, p. 61) studied teacher's advice to students and they found that hedging was employed in advice contexts to mitigate the force of utterances. As Locher (2006, p.114) mentions hedge use is perceived as normal in cultures where advice is taken as face-threatening. On the contrary, it is striking to observe that although advice as a speech act is not risky in Turkish culture (Bayraktaroğlu, 2001 ) when compared to Anglo-Saxon cultures (Locher, 2006 ; Brown \& Levinson, 1987; Hinkel, 1994; Hinkel,1997) still the results of our study indicate that hedges are employed to reduce its risky nature.

Therefore, it can be said that in our corpus the agony aunt cautiously downtones the advice she is giving to her problem-seekers which demonstrates her hesitation of losing face and self-esteem while advising her readers. There may be two reasonable interpretations for doing so: First, the agony aunt may consider protecting herself as there can be many interpretations of advice. Second, she can consider the advice-seeker's face needs by employing a mitigation on the advice she is giving (Locher, 2006, p.116).

Table 3. Overall Distribution of the main categories of hedging devices in the Turkish agony aunts column:

\begin{tabular}{llll}
\hline Category & Function & $\mathrm{N}$ & $\%$ \\
\hline Epistemic Hedges & Clarify the writer's stance & 192 & $43.4 \%$ \\
Lexical Hedges & $\begin{array}{l}\text { Soften the strength of } \\
\text { statements }\end{array}$ & 2 & $0.4 \%$ \\
Possibility Hedges & $\begin{array}{l}\text { Express probability } \\
\text { Downplay the significance } \\
\text { Downtoners }\end{array}$ & 0 & $6.7 \%$ \\
\hline
\end{tabular}




\begin{tabular}{lllc}
\hline Assertive Pronouns & $\begin{array}{l}\text { Highlight the significance } \\
\text { of propositions }\end{array}$ & 14 & $3.1 \%$ \\
Adverbs of Frequency & $\begin{array}{l}\text { Express prevalence of } \\
\text { occurence in statements }\end{array}$ & 4 & $0.9 \%$ \\
$\begin{array}{l}\text { Self mention(i.e. } \\
\text { direct/indirect person } \\
\text { markers) }\end{array}$ & $\begin{array}{l}\text { Refer to the view point of } \\
\text { the author directly or } \\
\text { indirectly }\end{array}$ & 38 & $8.5 \%$ \\
Universal Pronouns & $\begin{array}{l}\text { Refer to general } \\
\text { authorship/audience } \\
\text { increase the size or effect } \\
\text { of statements }\end{array}$ & 115 & $4.2 \%$ \\
Amplifiers & $\begin{array}{l}\text { Emphasize force or } \\
\text { writers' certainty in } \\
\text { message }\end{array}$ & 28 & $26.0 \%$ \\
Emphatics & & 442 & 100 \\
\hline
\end{tabular}

The total number of words in the advice letters were 6768 , and the number of letters written by the agony aunt were 50 as mentioned previously and the total number of hedging employed within advice context was 442. According to the table, there were two metadiscursive markers that were frequently employed by the agony aunt respectively Epistemic Hedges and Amplifiers. Epistemic hedges were the most frequently used category in advice column which formed $43.4 \%$ (192) of the metadiscursive markers in the corpus. This finding is consistent with Hyland \& Hyland (2012, p.196) and their study of teacher feedbacks where they found the extensive use of hedges for toning down criticisms in order to establish a good relation and rapport with the students.

Example from our data is as the following:

\section{Example 1:}

Karşılaştı̆̆ın şiddet giderek artabilir, çünkü erkeğin eli bir kere kalktı mı arkası gelir... Hemde çok can yakacak şekle dönüşebilir. (3 Ağustos 2018) (G34)

(The violence you are facing may increase day by day, because once a man's hand lays on you it will continue. It can turn into an ordeal.)

In the example given the agony aunt accounts for the advice-seeker's situation in a cautious manner. She assesses the situation of the advice-seeker by considering the possible options. The agony aunt employs various epistemic hedges to give advice to problem-seekers which indicates the multifunctional purposes of epistemic hedges in various cultures.

The second most frequently employed metadiscursive marker in our data is the employment of amplifiers which form 26,01\% (115) of the data. Similar to hedges, amplifiers that belong to informal discourse (Hinkel, 2005, p. 31) fulfill different functions in different cultures. In Turkish culture, for example, amplifiers have the effect of indicating the reliability of a proposition and they can also add some uncertainty to negative verbs as well (Doyuran, 2009, p.96). In English culture amplifiers have the effect of exaggerating and creating hyperbole (Hinkel, 2005, p.31). Leech (1983, p.146) reports that amplifiers enhance politeness and shows your interest in the topic. In some other cultures such as Arabic, Chinese, Japanese, Korean and Vietnamese where exaggerations and overstatements are expected in 
terms of rhetorical devices, amplifiers can indicate indirectness, persuasiveness (Oliver, 1972) (Hinkel, 2005, p.34) and emphasis and intensity as well (Taylor, 1995).

\section{Example 2:}

Eşin de belli ki, senin bu aşırı kıskançlığından fazlasıyla şikayetçi. (24 Temmuz 2020)

(It is certain that your husband is also complaining about your extreme jealousy.)

In example 2, the agony aunt shows empathy to his advice-seeker and indicates that she understands her related to the sexual desire the advice-seekers husband demonstrates. The use of the amplifier aşırı 'extreme' by the agony aunt.

Another example from the data is as the following:

\section{Example 3:}

Sevgili kızım, ben "Beni dövüyor ama aslında seviyor" diyebilen kadınlar için gerçekten çok üzülüyorum. (16 Nisan 2018)

(My dear, I really feel extremely sorry for women who can say 'He beats me but in reality he loves me'.)

In this example, the advice-seeker's husband is beating her and she shares this problem with the agony aunt by defending her husband saying he loves me. Since the agony aunt is against violence she uses two intensifiers 'really' and 'extremely' to strenghten her proposition and at the same time she indicates her certainty.

Example 4:

İster Batı ülkelerinde olsun, ister bizde, amaçları sadece biraz eğlenmektir; çünkü bir genç kızı heyecanlandırdıklarını görerek bundan aşırı keyif alırlar.

(Whether in Western countries or in our country, their aim is just to have a little fun; because they get extreme pleasure from their ability to excite a girl.)

According to the table, other metadiscursive categories (i.e. self-mentions, possibility hedges, emphatics, universal pronouns, assertive pronouns, lexical hedges) were infrequently used metadiscursive markers in the corpus. The metadiscursive category downtoners were not employed by the agony aunt. This section of the article attempts to account for the infrequent uses other metadiscursive categories.

Accounting for the less frequent forms of hedges:

Self-mention forms, Possibility Hedges, Assertive Pronouns, Adverbs of Frequency, Lexical Hedges

In our corpus, self-mention forms formed 8,5\% (38) of the data. Contary to academic texts which are formal (Hyland, 2001), advice letters considered as informal pieces of discourse, we observe the use of self-mention forms more often. Nonetheless, all writing carries some information about the author but it is the writer's task to project himself or not which is consciously done (Hyland, 2001).

After self-mention forms, respectively possibility markers that form 6,7\% (30) of the data, Assertive pronouns that form $3,1 \%$ of the data (14), adverbs of frequency forms that form $0,9 \%$ (4) of the data and lexical hedges formed $0,4 \%$ (2) of the data were found to be less-frequent forms in the corpus.

Possibility hedges formed $6,7 \%$ (30) of the data, while lexical hedges formed $0,4 \%(2)$ of the data. This can be attributed to the fact that Turkish language uses a rich variety of epistemic hedges in 
giving advice and as a result, possibility hedges and lexical hedges were not the preferred markers in advice letters written by the agony aunt.

\section{Lexical hedges, assertive pronouns and adverbs of frequency}

Varying in their degree of formality, adverbs of frequency similar to lexical hedges and assertive pronouns are defined as 'inherently vague' (Channel, 1994).Considered from this perspective, the agony does not want to present herself as someone who is giving advice in a vague fashion.

The third frequently employed category is the use of lexical hedges that form $14,6 \%$ (77) of the data. The difference between epistemic hedges and lexical hedges lies in the fact that while epistemic hedges modify the entire proposition, lexical hedges modify and delimit the meanings of nouns, adjectives and adverbs (Quirk et al., 1985).

\section{Accounting for the less frequent forms of boosters: Emphatics, Universal Pronouns}

There were two infrequent use of boosters respectively, universal pronouns and emphatics. Emphatics were used 6,3\% (28) of the data. According to Hyland (1998, p.19) the use of emphatics create a 'credible image of authority'. Hyland (1998, p.17) studied CEOs letters and found that the frequent use of emphatics demonstrated a confident, decisive image indicating assurance and conviction. Since agony aunt does not want to create an auhoritative image for herself as she is interacting with her readers in a friendly way, she does not employ emphatics frequently in the corpus.

Second infrequent form in the data was universal pronoun forms which comprised 4,2\% (19) of the data. The infrequent use of these markers could be attributed to the their being marked as exaggeratives and similar to English academic writing style they are not encountered in Turkish language as well (Halliday \& Hasan, 1976). Since these markers carry positive and negative polarity when generalising something with every- and no-, it can be said that the Turkish agony aunt refrains from making over generalizations in her letters.

\section{Conclusion}

Through the employment of hedges and boosters or more generally metadiscursive items, a successful communication is established. In other words, when giving advice if the speaker is able to use these interactional markers in the right place, this may indicate that he can give advice successfully or he can complain without being impolite. Thus, being aware of these interactional markers and the study of them linguistically can open up new horizons for communication and for societies. This study uncovered the use of hedges and boosters in advice giving in an agony aunt's column and thus dealt with non-academic discourse. Other speech acts (i.e. complaints) can be studied through the use of hedges and boosters and the metadiscursive features of non-academic texts can reveal the cultural elements of societies.

The results of the study indicate that although in Turkish culture where advice opens up space for sharing problems with other people and establish solidarity, in our corpus hedges were employed to mitigate the force of advice-giving by the agony aunt.

In the corpus examined, epistemic hedges and amplifiers were employed by the agony aunt to give advice to the advice-seekers. It can be said that in Turkish language epistemic hedges are used frequently to save face and the varieties of epistemic hedges have the power of giving advice to the advice-seekers. The extensive use of amplifiers can be seen as a way to persuade advice-seekers to perform the advice the agony aunt is giving. Nevertheless, Turkish advice requires to be studied from many angles. Other speech acts, a part from advice could be studied as well to interpret the use of hedges and boosters in specific languages. 


\section{Ethics Committee Approval}

The author(s) confirm(s) that the study does not need ethics committee approval according to the research integrity rules in their country (Date of Confirmation: August 27, 2020).

\section{References}

Bayyurt, Y. (2010). Author positioning in academic writing. In Zyngier, S. \& Viana, V. (Eds),Avaliaçoes e perspectivas: mapeando os estudos empiricos na area deHumanas (Appraisals and perspectives: mapping empirical studies in the Humanities) 163-184. Rio de Janeiro: The Federal University of Rio de Janeiro.

Brown, P.and S. Levinson . (1987). Politeness. Some Universals in Language Use. Cambridge: CUP.

Bayraktaroğlu, A. (2001). Advice-giving in Turkish. Superiority or Solidarity. Linguistic Politeness Across Boundaries: The Case of Greek and Turkish. 177-208. Ed. by. Arın Bayraktaroğlu and Maria Sifianou. John Benjamins.

Channel, J. (1994). Vague language. Oxford: Oxford University Press.

Doyuran, Z. (2009). Conciliation of Knowledge through Hedging in Turkish Scientific Articles. Edebiyat Fakültesi Dergisi. Journal of Faculty of Letters, 26(1), 85-99.

Halliday, M. A. K., \& Hasan, R. (1976). Cohesion in English. London: Longman.

Hedge (2020) In Collins Dictionary retrived from https://www.collinsdictionary.com/dictionary/english

Hinkel, E. (1994). Native nonnative speakers' pragmatic interpretations of English texts. TESOL Quarterly, 28(2), 353-376.

Hinkel, E. (1997). Indirectness in L1 and L2 academic writing. Journal of Pragmatics, 27(3), 360-386.

Hinkel, E. (2005). Hedging, Inflating, and Persuading in L2 Academic Writing. Applied Language Learning. 15(1\&2), 29-53.

Hyland, K. (2001). Humble-servants of the discipline? Self-mention in research articles. English for specific purposes. 207-226.

Hyland, K. (1998). Exploring Corporate Rhetoric: Metadiscourse in the CEO's letter. Journal of Business Communication, 35(2), 224-245.

Hyland, K. \& Hyland, F. (2012). 'You could make this clearer': Teachers' advice on ESL academic writing. Ed. By. Holger Limberg and Miriam Locher. Advice in Discourse. 53-71. Amsterdam: John Benjamins.

Kussmaul, P. (1997). Text-type conventions and translating. Text Typology and Translation. Ed. Anna Trosborg. Amsterdam: John Benjamins.

Leech, G. (1983). Principles of Pragmatics. London: Longman.

Lancaster, Z \& Aull, L. (2014). Linguistic Markers of Stance in Early and Advanced Academic Writing: A Corpus-based Comparison. Written Communication. 1-33. Sage.https://doi.org/ 10.1177/0741088314527055. 
Locher, M. (2006). Internet Advice. Advice Online. Pragmatics of Computer-Mediated Communication. 339-362. Amsterdam: John Benjamins.

Lakoff, G. (1972). Hedges: a study in meaning criteria and the logic of fussy concepts. The 8th Regional Meeting of the Chicago Linguistic Society: 183-228.Sage.

Quirk, R., Greenbaum, S., Leech, G. \& Svartvik, J. (1985). A Comprehensive Grammar of the English Language. New York: Longman.

Morrow, P. R. (2012). Online advice in Japanese: Giving advice in an Internet discussion forum. Advice in Discourse. Ed. by. Holger Limberg and M.A. Locher. 255-279.Amsterdam: John Benjamins Company.

Oliver, R. T. (1972). Communication and culture in ancient India and China. Syracuse, NY: Syracuse University Press.

Spencer-Oatey, H. (2008). 'Face, (Im)politeness and Rapport'. Culturally Speaking: Culture, Communication and Politeness. London: Continuum.

Spencer-Oatey, H. \& Ruhi, Ş. (2007). Identity, face and (im)politeness. Journal of Pragmatics, 39, 635638.

Taylor, I. (1995). Writing and literacy in Chinese, Korean, and Japanese. Amsterdam: John Benjamins.

Yarar, E. (2001). Akademik Söylemde Belirteçlerin Olasılık ve Belirsizlik İşlevleri. Hacettepe Üniversitesi Edebiyat Fakültesi Dergisi. 1(1).128-138.

\section{Ögüt vermenin metasöylemsel boyutları: Güzin abla köşesinde Kaçınmacı ve vurgulayıcılar yapılar}

\section{$\ddot{O} \mathbf{z}$}

Öğüt vermenin kültürden kültüre değişen bir durum olduğu bilinen bir gerçektir. Bazı kültürler öğüt vermeden kaçınırken, Türk kültürü gibi bazı kültürler öğütü yakınlık göstergesi olarak algılarlar. Böylece, öğütün bu doğasını önlemek amacıyla metasöylemsel öğeler kullanılarak dille bağlantılı önlemler alınır. Öğütü dilin metasöylemsel özelliklerini anlamak için başlangıç noktası alarak, bu çalışma öğüt vermedeki eğilimleri araştırmayı hedeflemektedir. Veriler nitelik ve nicelik bakımından incelenecek, ve araştırma kaçınmacı ve vurgulayıcı yapıların kullanımındaki örnekleri ortaya çıkartacaktır. Buna ek olarak,metapragma öğelerin kullanım bağlamları ayırtedilip, ögüt verme eyleminde kaçınmacı ve vurgulayıcı yapı tercihlerini orataya koyulacaktır. Araştırmanın bulguları söz eylemlerde kaçınmacı ve vurgulayıcı yapıların kullanımı ve bunların yorumları o söz eyleme özel olarak değerlendirilmeli ve kültürlerin öğüt vermede kullandıkları yapılar bu çalışmada ortaya konulacaktır. 


\section{AUTHOR BIODATA}

Suhan Akıncı Oktay is a lecturer at Hacettepe University English Linguistics department. She got her PhD from Hacettepe University English Linguistics Department in 2007. Her main areas of interest include pragmatics, metadiscourse, politeness, impoliteness, speech acts, stylistics. 